\title{
Analisis Faktor-Faktor yang Mempengaruhi Keputusan Etnis Tionghoa Menggunakan Jasa Bank Syariah
}

\author{
Jasri \\ Pascasarjana Universitas Islam Negeri Alauddin Makassar \\ Email:jasri@unismuh.ac.id \\ Salma Said \\ Universitas Islam Negeri Alauddin Makassar \\ Email:salmahsaid@uin-alauddin.ac.id \\ Amiruddin $\mathbf{K}$. \\ Universitas Islam Negeri Alauddin Makassar \\ Email:amir.uin@yahoo.com3
}

\begin{abstract}
:
Chinese ethnic is one of the ethnic groups in Indonesia. The majority of Chinese ethnics are nonMuslim. In the midst of differences in perceptions who looked cynically following Islamic banking, most of the Chinese ethnics who are not Muslim prefer sharia banking to transact. So, this research studies the factors that influence the decision of ethnic of Chinese non-Muslim to use the services of Islamic banks. This type of research used in this research is quantitative field research thas emphasizes the aspect of objective assessment pf social phenomena where the independent variables are Environtment $\left(\mathrm{X}_{1}\right)$, Psychology $\left(\mathrm{X}_{2}\right)$, and Promotion $\left(\mathrm{X}_{3}\right)$ and the dependent variation is the decision of ethnic of Chinese $(\mathrm{Y})$. This study uses SPSS software as a tool in prosessing statistical data. The results show simultaneously three factors which were considered as significant to the decision of the ethnic of Chinese to use the services of Islamic banks. If it is related to environmental factors $\left(\mathrm{X}_{1}\right)$ and Promotion $\left(\mathrm{X}_{3}\right)$ influences and significantly influences ethnic of Chinese decisions, while psychology $\left(\mathrm{X}_{2}\right)$ does not relate to outcome of the ethnic of Chinese agreement using the services of Islamic banks.

[Etnis Tionghoa merupakan salah satu etnis yang ada di Indonesia. Mayoritas etnis Tionghoa memeluk agama non-Muslim. Di tengah-tengah banyaknya persepsi dari berbagai kalangan termasuk umat Muslim sendiri yang memandang sinis kehadiran perbankan syariah, sebagian etnis Tionghoa yang non-Muslim justru memilih perbankan syariah untuk bertransaksi. Maka penelitian ini bertujuan untuk mengetahui faktor-faktor yang mempengaruhi keputusan etnis Tionghoa non-Muslim menggunakan jasa bank syariah. Jenis penelitian yang digunakan dalam penelitian ini yaitu field research kuantitatif yang lebih menekankan pada aspek pengukuran secara objektif terhadap fenomena-fenomena sosial. Dimana variabel independent yaitu lingkungan $\left(\mathrm{X}_{1}\right)$, Psikologi $\left(\mathrm{X}_{2}\right)$, dan Promosi $\left(\mathrm{X}_{3}\right)$ dan variabel dependent yaitu keputusan etnis Tionghoa $(\mathrm{Y})$. Penelitian ini menggunakan software SPSS sebagai alat bantu dalam mengolah data statistik. Hasil penelitian menunjukkan secara simultan ketiga faktor yang diteliti berpengaruh secara signifikan terhadap keputusan etnis Tionghoa menggunakan jasa bank syariah. Jika diukur secara parsial maka faktor lingkungan (X1) dan Promosi $\left(\mathrm{X}_{3}\right)$ berpengaruh dan signifikan terhadap keputusan etnis Tionghoa, sedangkan Psikologi $\left(\mathrm{X}_{2}\right)$ tidak berpengaruh terhadap keputusan nasabah etnis Tionghoa menggunakan jasa bank syariah.]
\end{abstract}

Kata Kunci: Lingkungan; Psikologi; Promosi; Keputusan Nasabah; Etnis Tionghoa. 
Jasri, Salma Said, Amiruddin K.

\section{PENDAHULUAN}

Perekonomian Islam dimulai dengan kehadiran perbankan syariah, yaitu bank yang menjalankan kegiatan usahanya berdasarkan prinsip syariah dan menurut jenisnya terdiri atas Bank Umum Syariah dan Bank Pembiayaan Rayat Syariah. ${ }^{1}$ Sebagai lembaga keuangan yang berlandaskan etika, dengan dasar al-Qur'an dan Hadis tentu dalam praktinya akan menghidari penggunaan instrument bunga (riba) dan beroperasi dengan prinsip bagi hasil. Tonggak utama berdirinya perbankan syariah adalah beroperasinya Local Saving Bank di Desa Mit Ghamr di tepi Sungai Nil, Kairo, Mesir, pada tahun 1960-an oleh Abd. Hamid alNaggar. ${ }^{2}$

Di Indonesia praktik perbankan syariah bermula pada tahun 1992, yang ditandai dengan beroperasinya Bank Muamalat Indonesia (BMI)3 dan merupakan bank pertama yang menerapkan sistem bagi hasil. Berdirinya bank ini diprakarsai oleh Majelis Ulama Indonesia (MUI) dan pemerintah serta dukungan dari Ikatan Cendekiawan Muslim Indonesia (ICMI) dan beberapa pengusaha muslim. ${ }^{4}$ Pada saat krisis moneter yang melanda Indonesia tahun 1998 dan memporak-porandakan perekonomian sehingga menyebabkan tingkat suku bunga dan inflasi menjadi tinggi, Bank Muamalat sebagai bank syariah pertama di Indonesia pun terkena imbasnya. Bank Muamalat mengalami kerugian Rp. 105 miliar. Pada tanggal 21 Juni 1999, Islamic Development Bank (IDB) secara resmi menjadi salah satu pemegang saham Bank Muamalat. 5

Berdasarkan data yang diperoleh dari situs resmi Otoritas Jasa Keuangan perkembangan jaringan kantor dan aset lembaga keuangan syariah dapat dilihat dari tahun 2014, jumlah bank syariah pada tahun 2014 hingga 2018 mengalami peningkatan, dari 12 unit bank pada tahun 2014 hingga 14 unit pada tahun 2018, jumlah bank umum konvensional yang memiliki UUS dari 22 unit tahun 2014 hingga 20 unit pada tahun 2018 karena sebagian dari UUS tersebut sudah memisahkan diri dari bank induknya. Peningkatan jumlah perbankan syariah tersebut tidak terlepas dari kebutuhan masyarakat terhadap perbankan syariah yang semakin meningkat. ${ }^{6}$

Berdasarkan data Badan Pusat Statistik (BPS) Sulawesi Selatan, maka etnis Tionghoa merupakan etnis dengan jumlah terbanyak kedua yang berada di Sulawesi selatan setelah etnis asal Sulawesi selatan sendiri, atau sebanyak 43.846 jiwa dari total 8.771 .970 jiwa penduduk Sulawesi Selatan. ${ }^{7}$ Sehingga keberadaannya tidak bisa dipandang sebelah mata sebagai salah satu sasaran pemasaran oleh perbankan syariah. Akan tetapi, sistem yang mengakar pada masyarakat Tionghoa di Indonesia yakni sistem kapitalisme yang berdasarkan pada unsur pengumpulan individualisme dan kekayaan, bercirikan kepemilikan individu. Di samping jiwa kapitalisme, dinyatakan bahwa pebisnis Tionghoapun memiliki

\footnotetext{
1Undang-Undang No. 21 Tahun 2008, Tentang Perbankan Syariah, Pasal 1 Ayat 7.

2Irwan Misbach, Bank Syariah: Kualilas Iayanan, Kepuasan, dan Kepercayaan. Makassar; Alauddin University Press, 2013, 25.

${ }^{3}$ Adiwarman A. Karim, Bank Islam: Anatisis Fiqh dan Keuangan. Jakarta: PT. Raja Grafindo Persada, $2010,25$.

4Erty Rospyana Rufaida and Alamsyah Alamsyah. "Metode Pengakuan Pendapatan Bagi Hasil."Jurnal Hukum Ekonomi Syariah, Vol. 3, No. 1 (Juni 2019): 27-39.

${ }^{5}$ Khaerul Umam, Manajemen Perbankan Syariah. Bandung: Pustaka Setia, 2013, 22.

6Jasri, Jasri. "Pendapatan Margin Bayal-Murabahah Terhadap Profitabilitas Pada Bank Syariah."Jurnal Hukum Ekonomi Syariah, Vol. 1 No. 1 (Juni 2017): 64-73.

${ }^{7}$ Badan Pusat Statistik Sulawesi Selatan, diakses dari https://sulsel.bps.go.id/quickMap.html pada 07 November 2019
}

2 
sikap yang kurang menyukai kerjasama. Sistem kapitalis tersebut diterapkan pada bank konvensional yang didasarkan pada adanya bunga (interest), keuntungan dan kerugian dimiliki salah satu pihak. Perbankan konvensional dalam jangka panjang yang mengadopsi sistem kapitalis tersebut, akan menyebabkan penumpukan kekayaan pada segelintir orang yang memiliki kapital besar. Sistem ekonomi ini di bangun atas dasar materialisme. Berbeda dengan perbankan konvensional, perbankan syariah menerapkan sistem bagi hasil yang berprinsip keadilan dan kesederajatan. Selain itu, dalam perbankan syariah diterapkan pula adanya sistem kerjasama (musyarakah), artinya keuntungan usaha dibagi menurut kesepakatan yang dituangkan dalam kontrak.

Melihat tantang di atas, maka hal utama yang berperan penting dalam keberhasilan bank syariah mendapatkan nasabah etnis Tionghoa adalah faktor promosi. Promosi yang dilakukan harus menarik agar dapat menarik nasabah menggunakan produk-produk yang ada di bank syariah. Menurut Kasmir promosi merupakan cara paling ampuh untuk menarik dan mempertahankan nasabahnya. ${ }^{8}$ Salah satu tujuan promosi adalah menginformasikan segala jenis produk yang ditawarkan dan berusaha menarik calon nasabah yang baru. Kemudian promosi juga berfungsi mengingatkan nasabah akan produk, promosi juga ikut mempengaruhi nasabah untuk membeli dan akhirnya promosi juga akan meningkatkan citra bank di mata para nasabah. ${ }^{9}$

Informasi tentang kunggulan bank syariah juga akan tersebar melalui promosi, sehingga masyarakat luas termasuk non muslim akan mengenal bank syariah secara tidak langsung tanpa harus mendatangi bank syariah untuk memperoleh informasi. Informasiinformasi tersebut akan diteruskan ke lingkungan kerja, lingkungan keluarga, dan di manapun masyarakat yang memperoleh informasi tersebut berada. Secara teori, lingkungan meliputi semua kondisi dalam dunia ini yang dengan cara-cara tertentu mempengaruhi tingkah laku kita, pertumbuhan, perkembangan atau life processes..$^{10}$ Lingkungan yang terdiri dari budaya, kelas sosial, dan keluarga tentu memiliki kekuatan yang sangat besar dalam mempengaruhi keputusan individu. ${ }^{11}$ Keberhasilan melalui bank syariah dalam memikat minat etnis Tionghoa diungkap Harvis dan Haroni melalui penelitiannya yang mengungkap bahwa pada PT. Bank Syariah Mega Indonesia di Kota Medan, kalangan etnis Tionghoa beramai-ramai menikmati produk bank tersebut. Meskipun, mayoritas enis Tionghoa adalah pedagang dan pebisnis yang menguasai perputaran uang di negeri ini dan berjiwa kapitalisme, tetapi sebanyak $\pm 42 \%$ nasabah PT Bank Syariah Mega Indonesia Kota Medan adalah kalangan etnis Tionghoa. ${ }^{12}$

Rostanti menyebutkan bahwa masyarakat non muslim termasuk diantaranya dari kalangan etnis Tionghoa di Indonesia semakin meminati produk yang ada di bank syariah,13 namun bila melihat kondisi akhir-akhir ini keadaan masyarakat di Indonesia sedikit terjadi kesenjangan antara muslim dan non-muslim, kesenjangan ini semakin diperparah dengan

\footnotetext{
${ }^{8}$ Kasmir, Pemasaran Bank. Jakarta: Kencana, 2010, 278.

${ }^{9}$ Agung Anugerah Adhi Pratama, "Analisis Faktor-Faktor yang Mempengaruhi Keputusan Nasaban Non Muslim untuk Menggunakan Bank Syariah", 8.

10Purwanto, Evaluasi Hasil Belajar. Yogyakarta: Pustaka Belajar, 2011, 72.

${ }^{11}$ Basu Swastha Dharmesta, Manajemen Pemasaran. Yogyakarta: BPFE, 2014, 4.3-4.5.

${ }^{12}$ Harviz Akbar dan Haroni Doli H. Ritonga, "Persepsi Etnis China terhadap Perbankan Syariah di Kota Medan", Jurnal Ekonomi dan Keuangan 1, No. 2 (Januari 2013), 42.

${ }^{13 R}$ Rostanti, "Non Muslim Makin Minati Produk Bank Syariah", http://www.republika.co.id./berita/ ekonomi/syariahekonomi/13/02/21/mikep8-nonmuslim-makin-minati-produk-bank-syariah. diakses 11 April 2019.
}

Iqtishadia: Jurnal Ekonomi dan Perbankan Syariah 
isu-isu etnis Tionghoa yang diberitakan banyak masuk secara bebas di Negara Indonesia. Hal tersebut juga berimbas di sosial media dimana masyarakat yang pro dan kontra saling menghujat satu sama lain. Situasi tersebut akan mempengaruhi motivasi, persepsi, keyakinan, dan bahkan sikap individu (etnis Tionghoa) dalam keputusannya memilih bank syariah. ${ }^{14}$

\section{METODE PENELITIAN}

Penelitian ini menggunakan field research kuantitaf yaitu metode penelitian yang lebih menekankan pada aspek pengukuran secara objektif terhadap fenomena sosial atau dengan kata lain penelitian yang dilakukan di masyarakat yang sebenarnya untuk menemukan realitas apa yang tengah terjadi mengenai masalah tertentu. Untuk melakukan pengukuran, setiap fenomena sosial dijabarkan dalam beberapa komponen masalah, variable dan indicator. Pendekatan yang digunakan dalam penelitian ini yaitu pendekatan filosofis. Pendekatan Filosofis digunakan untuk mengarahkan cara berpikir mensistematiskan pembahasan dengan menggunakan kerangka berpikir yang ilmiah. Dengan menggunakan pendekatan ini, penulis dapat menyajikan hasil penelitian secara sistematis dan disesuaikan dengan ketentuan-ketentuan dalam metodologi penelitian dan penulisan karya ilmiah. Populasi dalam penelitian ini kurang dari 100 orang. Teknik pengambilan sampel dalam penelitian ini yaitu menggunakan probality sampling. Menurut Arikunto apabila populasi kurang dari 100 maka keseluruhan anggota populasi menjadi sampel penelitian. ${ }^{15}$ Maka semua populasi dalam penelitian ini menjadi sampel penelitian. Tekni pengumpulan data dilakukan dengan menyebar kuesioner kepada seluru responden yang menjadi sampel penelitan.

\section{Metode Analisis \\ Uji Kualitas Data}

Uji kualitas data dalam penelitian ini yaitu menggunakan 1) uji validasi dan reliabilitas untuk memastikan bahwa instrument yang digunakan sebagai alat pengumpul data merupakan instrument yang tepat. 2) uji asumsi klasik yang terdiri dari uji normalitas, uji heteroskedastisitas, uji autokorelasi, dan uji multikoloneritas. Uji ini digunakan untuk memastikan bahwa data yang digunakan dalam penelitian ini bebas dari penyimpanganpenyimpangan klasik.

\section{Uji Hipotesis}

Pengujian ini dilakukan untuk menjawab hipotesis dalam penelitian ini, adapun pengujian yang dilakukan yaitu 1) uji regresi linear berganda untuk melihat apakah terdapat pengaruh atau tidak antara variabel independen terhadap variabel dependen, selanjutnya 2) uji determinan $\left(R^{2}\right)$ untuk mengetahui seberapa persen tingkat pengaruh variabel independen terhadap variabel dependen. 3) uji t digunakan untuk mengetahui pengaruh secara parsial antara variabel independen terhadap variabel dependen.

\footnotetext{
${ }^{14}$ Kotler dan Amstrong terj. Damos Sihombing, Prinsip-Prinsip Pemasaran. Jilid I, Ed. XII; Jakarta: Erlangga, 2008, 172.

${ }^{15}$ Arikunto, S., Prosedur Penelitian Suatu Pendekatan Praktik. Jakarta: Rineka Cipta, 2010, 134.

4

Iqtishadia: Jurnal Ekonomi dan Perbankan Syariah

Vol.7 No.1 Juni 2020
} 


\section{HASIL DAN PEMBAHASAN Uji Validasi}

Uji validasi adalah prosedur untuk memastikan apakah kuesioner yang akan dipakai untuk mengukur variabel penelitian valid atau tidak. Kuesioner dapat dikatakan valid jika pernyataan pada kuesiner mampu untuk mengungkapkan sesuatu yang diukur oleh kuesioner tersebut. Untuk mengetahui item pernyataan tersebut itu valid dengan melihat nilai Corrected Item Total Corelation. Apabila item pernyataan mempunyai nilai $r$ hitung > nilai $r$ tabel maka dapat dikatakan valid. Pada penelitian ini terdapat jumlah sampel $(n)=72$ responden dan besarnya df dapat dihitung 72-2 $=70$ dengan $\mathrm{df}=70$ dan $a l p h a=0,05$ di dapat nilai $r=0,1954$. Jadi, item pernyataan yang valid memiliki nilai $r$ hitung $>0,1954$.

Tabel 1 tersebut memperlihatkan bahwa seluruh item pernyataan dari variabel yang diteliti telah memiliki nilai koefisien korelasi positif dan lebih besar daripada nilai $\mathrm{r}_{\text {tabel }}$ sebesar 0,1954. Hal ini berarti bahwa item-item pernyataan kuesioner yang diperoleh telah valid dan dapat dilakukan pengujian data lebih lanjut. Adapun hasil uji validasi data dalam penelitian ini dapat dilihat lebih detail pada tabel 1berikut.

Tabel 1

Hasil Uji Validasi

\begin{tabular}{|c|c|c|c|c|}
\hline Variabel & Item & $\mathbf{r}_{\text {hitung }}$ & $\mathbf{r}_{\text {tabel }}$ & Keterangan \\
\hline \multirow[t]{5}{*}{ Lingkungan } & $\mathrm{X} 1.1$ & 0.767 & \multirow[t]{5}{*}{0,235} & Valid \\
\hline & $\mathrm{X} 1.2$ & 0.738 & & Valid \\
\hline & $\mathrm{X} 1.3$ & 0.695 & & Valid \\
\hline & $\mathrm{X} 1.4$ & 0.695 & & Valid \\
\hline & $\mathrm{X} 1.5$ & 0.738 & & Valid \\
\hline \multirow[t]{5}{*}{ Psikologi } & $\mathrm{X} 2.1$ & 0.762 & \multirow[t]{5}{*}{0,235} & Valid \\
\hline & $\mathrm{X} 2.2$ & 0.715 & & Valid \\
\hline & $\mathrm{X} 2.3$ & 0.694 & & Valid \\
\hline & $\mathrm{X} 2.4$ & 0.650 & & Valid \\
\hline & $\mathrm{X} 2.5$ & 0.705 & & Valid \\
\hline \multirow[t]{5}{*}{ Promosi } & X3.1 & 0.860 & \multirow[t]{5}{*}{0,235} & Valid \\
\hline & X3.2 & 0.858 & & Valid \\
\hline & $\mathrm{X} 3.3$ & 0.925 & & Valid \\
\hline & X3.4 & 0.868 & & Valid \\
\hline & $\mathrm{X} 3.5$ & 0.727 & & Valid \\
\hline \multirow[t]{5}{*}{ Keputusan } & Y1 & 0.835 & \multirow[t]{5}{*}{0,235} & Valid \\
\hline & $\mathrm{Y} 2$ & 0.813 & & Valid \\
\hline & Y3 & 0.836 & & Valid \\
\hline & $\mathrm{Y} 4$ & 0.862 & & Valid \\
\hline & Y5 & 0.793 & & Valid \\
\hline
\end{tabular}

Sumber: Data primer, diolah 2019

\section{Uji Reliabilitas}

Uji reliabilitas digunakan untuk mengukur suatu kuesioner yang merupakan indicator dari variabel. Suatu kuesioner dikatakan reliabel atau handal jika jawaban seseorang terhadap pernyataan adalah konsisten atau stabil dari waktu ke waktu. Uji reliabilitas data dilakukan dengan menggunakan metode alpha cronbach yaitu suatu instrumen dikatakan

Iqtishadia: Jurnal Ekonomi dan Perbankan Syariah 
Jasri, Salma Said, Amiruddin K.

reliabel apabila memiliki koefisien keandandalan reliabilitas sebesar 0,60 atau lebih. Hasil pengujian reliabilitas data dapat dilihat pada tabel 2 berikut:

Tabel 2

Hasil Uji Reliabilitas

\begin{tabular}{|c|l|c|c|}
\hline No. & Variabel & Cronbach's Alpha & Keterangan \\
\hline 1 & Lingkungan & 0.814 & Reliabel \\
\hline 2 & Psikologi & 0.805 & Reliabel \\
\hline 3 & Promosi & 0.822 & Reliabel \\
\hline 4 & Mashlahah & 0.826 & Reliabel \\
\hline 5 & Keputusan & 0.839 & Reliabel \\
\hline
\end{tabular}

Sumber: Data primer, diolah 2019

Tabel 2 tersebut memperlihatkan bahwa nilai alpha cronbach semua variabel lebih besar dari 0,60, sehingga dapat disimpulkan bahwa instrument kuesioner yang digunakna untuk menjelaskan variabel lingkungan, psikologi, promosi, mashlahah, dan keputusan dapat dikatakan handal atau dapat dipercaya sebagai alat ukur variabel.

\section{Hasil Uji Validasi dan Reliabilitas}

Uji asumsi klasik dilakukan dengan tujuan untuk melihat apakah asumsi-asumsi yang diperlukan dalam analisis regresi linear terpenuhi. Uji asumsi klasik dalam penelitian ini menguji normalitas data secara statistik, uji heteroskedasitas, uji autokorelasi, dan uji multikolonieritas.

\section{Uji Normalitas}

UJi normalitas dilakukan agar dapat melihat variabel-variabel yang digunakan untuk menguji hipotesis telah terdistribusi normal atau tidak. Uji normalitas dalam penelitian ini dilakukan dengan menggunakan dua cara, yaitu kolmogorov smirnov dan normal probability plot. Uji kolmogorov smirnov lebih sering digunakan karena menghasilkan angka-angka yang lebih detail dan hasilnya dapat dipercaya. Suatu persamaan regresi dapat dikatakan normal apabila nilai probabilitas kolmogorov-smirnov lebih besar dari 0,05. Hasil uji kolmogorovsmirnov dapat dilihat pada tabel 3 berikut:

\section{Tabel 3}

\section{Hasil Uji Normalitas- Kolmogorov-Smirnov One-Sample Kolmogorov-Smirnov Test}

\begin{tabular}{llr} 
& & Unstandardized Residual \\
\hline N & & 72 \\
\hline Normal Parameters & Mean & .0000000 \\
\cline { 2 - 3 } Most Extreme Differences & Std. Deviation & 3.13356834 \\
\cline { 2 - 3 } & Absolute & .082 \\
\cline { 2 - 3 } & Positive & .064 \\
\cline { 2 - 3 } & Negative &. .082 \\
\hline Test Statistic & & .082 \\
\hline Asymp. Sig. (2-tailed) & & $.200^{\mathrm{c}, \mathrm{d}}$ \\
\hline Sumber: Output SPSS 25 (2019) & &
\end{tabular}


Berdasarkan tabel 3 dapat dilihat signifikansi nilai kolmogorov-smirnov yang ditunjukkan dengan asymp sig (2-tailed) berada di atas 0,05 atau 5\% yaitu sebesar 0,200 atau $20 \%$. Hal tersebut menunjukkan bahwa data atau variabel-variabel dalam penelitian ini terdistribusi nornal.

\section{Uji Heteroskedastisitas}

Uji heteroskedastisitas bertujuan menguji apakah dalam model regresi terjadi ketidaksamaan variance dari residual satu pengamatan ke pengamatan yang lain. Mendeteksi adanya heteroskedastisitas dapat dilakukan dengan menggunakan uji glejser. Uji glejser digunakan untuk memperkuat hasil dari grafik scatter plot. Jika nilai probabilitas $>0,05$ maka tidak terjadi gejala heteroskedastisitas, apabila nilai probabilitas $<0,05$ maka terjadi gejala heteroskedastisitas. Hasil pengujiannya dapat dilihat pada tabel 4 berikut:

\begin{tabular}{|c|c|c|c|c|c|c|}
\hline & \multicolumn{6}{|c|}{$\begin{array}{c}\text { Tabel } 4 \\
\begin{array}{c}\text { Hasil Uji Heteroskedastisitas - Uji Glejser } \\
\text { Coefficients }^{\mathrm{a}}\end{array}\end{array}$} \\
\hline & & \multicolumn{2}{|c|}{$\begin{array}{l}\text { Unstandardized } \\
\text { Coefficients }\end{array}$} & \multirow{2}{*}{$\begin{array}{l}\text { Standardized } \\
\text { Coefficients } \\
\text { Beta }\end{array}$} & \multirow[b]{2}{*}{$\mathrm{t}$} & \multirow[b]{2}{*}{ Sig. } \\
\hline \multicolumn{2}{|c|}{ Model } & $\mathrm{B}$ & Std. Error & & & \\
\hline \multirow[t]{5}{*}{1} & (Constant) & 3.910 & 7.292 & & .536 & .594 \\
\hline & Lingkungan (X1) & .546 & .284 & .199 & 1.922 & .059 \\
\hline & Psikologi (X2) & -.037 & .130 & -.029 & -.283 & .778 \\
\hline & Promosi (X3) & .469 & .098 & .494 & 4.791 & .000 \\
\hline & Mashlahah (M) & -.300 & .159 & -.195 & -1.891 & .063 \\
\hline
\end{tabular}

Berdasarkan hasil uji glejser pada tabel 4 dapat disimpulkan bahwa nilai probabilitas variabel independen (lingkungan, psikologi, promosi, dan mashlahah) berada di atas tingkat signifikan 0,05, jadi variabel dalam penelitian ini terbebas dari heteroskedastisitas.

\section{Uji Autokorelasi}

Uji autokorelasi bertujuan untuk menguji dalam model regresi linear ada atau tidak korelasi antara kesalahan pengganggu pada periode t dengan kesalahan pengganggu pada periode t-1 atau periode sebelumnya. Menurut Imam Ghazali, tidak ada gejala autokorelasi jika nilai Durbin Watson terletak antara dU sampai dengan 4-dU. Hasil uji autokorelasi dapat dilihat pada tabel 5 berikut:

\begin{tabular}{|c|c|c|c|c|c|}
\hline \multicolumn{6}{|c|}{$\begin{array}{c}\text { Tabel } 5 \\
\text { Hasil Uji Autokorelasi } \\
\text { Model Summaryb }\end{array}$} \\
\hline Model & $\mathrm{R}$ & R Square & $\begin{array}{l}\text { Adjusted R } \\
\text { Square }\end{array}$ & $\begin{array}{l}\text { Std. Error of } \\
\text { the Estimate }\end{array}$ & $\begin{array}{l}\text { Durbin- } \\
\text { Watson }\end{array}$ \\
\hline 1 & $.520^{\mathrm{a}}$ & .270 & .238 & 3.202 & 2.221 \\
\hline
\end{tabular}

Berdasarkan tabel 5 di atas nilai Durbin Watson sebesar 2.221, pembanding menggunakan nilai signifikansi 5\%, jumlah sampel 72 (n), dan jumlah variabel independen 3 $(\mathrm{k}=3)$, maka di tabel Durbin Watson akan didapat nilai dU sebesar 1,5323. Karena nilai dW

Iqtishadia: Jurnal Ekonomi dan Perbankan Syariah

Vol. 7 No. 1 Juni 2020 
Jasri, Salma Said, Amiruddin K.

2,221 lebih besar dari batas atas (dU) 1,5323 dan kurang dari 4 - 1,5323 (2,4677), maka dapat disimpulkan bahwa tidak terdapat autokorelasi pada variabel dalam penelitian ini.

\section{Uji Multikolonieritas}

Uji multikolonieritas bertujuan untuk menguji apakah model regresi ditemukan kolerasi atau hubungan antar variabel bebas (independen). Model regresi yang baik seharusnya tidak terjadi atau hubungan di antara variabel independen. Pengujian multikolonieritas dapat dilihat dari Tolerance Value atau Variance Inflation Factor (VIF), sebagai berikut: a) Jika nilai tolerance $>0,10$ dan VIF $<10$, maka dapat disimpulkan bahwa tidak terjadi gejala multikolonieritas, b) Jika nilai tolerance $<0,10$ dan VIF $>10$, maka dapat disimpulkan bahwa terjadi gelaja multikolonieritas.

\begin{tabular}{|c|c|c|c|}
\hline \multicolumn{4}{|c|}{$\begin{array}{c}\text { Tabel } 6 \\
\text { Hasil Uji Multikolonieritas }\end{array}$} \\
\hline & & \multicolumn{2}{|c|}{ Collinearity Statistics } \\
\hline \multicolumn{2}{|c|}{ Model } & Tolerance & VIF \\
\hline \multirow[t]{5}{*}{1} & (Constant) & & \\
\hline & Lingkungan (X1) & .963 & 1.038 \\
\hline & Psikologi (X2) & .980 & 1.020 \\
\hline & Promosi (X3) & .972 & 1.029 \\
\hline & Mashlahah (M) & .973 & 1.027 \\
\hline
\end{tabular}

Berdasarkan hasil pengujian pada tabel 6 diatas, nilai tolerance yang menunjukkan nilai $>0,10$. Di mana variabel lingkungan senilai 0,986 , psikologi senilai 0,980 , promosi senilai 0,973 dan mashlahah senilai 0,972 . Nilai VIF untuk semua variabel memiliki nilai $<10$, di mana variabel lingkungan senilai 1,038 , psikologi senilai 1,020 , promosi senilai 1,029 dan mashlahah senilai 1,027. Hal ini menunjukkan bahwa tidak terdapat gejala multikolonieritas antar variabel independen karena semua nilai tolerance $>0,1$ dan nilai VIF $<10$.

\section{Hasil Uji Hipotesis}

Teknik analisis yang digunakan untuk menguji hipotesis $\mathrm{H}_{1}, \mathrm{H}_{2}, \mathrm{H}_{3}$ menggunakan analisis regresi berganda dengan meregresikan variabel independen (lingkungan, psikologi, dan promosi) terhadap variabel dependen (keputusan etnis Tionghoa). Uji hipotesis ini dibantu dengan menggunakan program SPSS versi 25.

\section{Hasil Uji Regresi Berganda Hipotesis Penelitian $\mathrm{H}_{1}, \mathrm{H}_{2}, \mathrm{H}_{3}$}

Pengujian hipotesis $\mathrm{H}_{1}, \mathrm{H}_{2}$, dan $\mathrm{H}_{3}$ dilakukan dengan analisis regresi berganda untuk menguji pengaruh variabel lingkungan, psikologi, dan promosi terhadap keputusan etnis Tionghoa. Hasil pengujian tersebut ditampilkan sebagai berikut:

\section{Tabel 7}

\section{Hasil Uji Koefisien Determinasi $\left(\mathrm{R}^{2}\right)$} Model Summaryb

\begin{tabular}{lr|r|r|r} 
Model & R & R Square & Adjusted R Square & Std. Error of the Estimate \\
\hline 1 & $.762^{\mathrm{a}}$ & .581 & .553 & 1.652 \\
\hline
\end{tabular}

a. Predictors: (Constant), Promosi (X3), Prikologi (X2), Lingkugan (X1) 
b. Dependent Variable: Keputusan (Y)

Sumber: Output SPSS 25 (2019)

Hasil uji koefisien determinasi pada tabel 7 menunjukkan nilai adjusted $r$ square dari model regresi digunakan untuk mengetahui seberapa besar kemampuan variabel bebas (independen) dalam menjelaskan variabel terikat (dependen) atau seberapa besar pengaruh variabel independen terhadap variabel dependen. Berdasarkan tabel 7 tersebut, nilai adjusted $r$ square sebesar 0,553, hal ini menunjukkan bahwa 55,3\% keputusan etnis Tionghoa dipengaruhi oleh variabel lingkungan, psikologi, dan promosi. sedangkan $44,7 \%$ dipengaruhi oleh variabel lain yang tidak diteliti dalam penelitian ini.

\begin{tabular}{|c|c|c|c|c|c|c|}
\hline \multicolumn{7}{|c|}{$\begin{array}{c}\text { Tabel } 8 \\
\text { Hasil Uji F - Uji Simultan } \\
\text { ANOVA }^{\mathrm{a}}\end{array}$} \\
\hline Model & & $\begin{array}{c}\text { Sum of } \\
\text { Squares }\end{array}$ & $\mathrm{df}$ & Mean Square & $\mathrm{F}$ & Sig. \\
\hline \multirow[t]{3}{*}{1} & Regression & 258.486 & 3 & 86.162 & 8.404 & $.000^{\mathrm{b}}$ \\
\hline & Residual & 697.167 & 68 & 10.252 & & \\
\hline & Total & 955.653 & 71 & & & \\
\hline
\end{tabular}

a. Dependent Variable: Keputusan (Y)

b. Predictors: (Constant), Promosi (X3), Lingkungan (X1), Psikologi (X2)

Sumber: Output SPSS 25 (2019)

Berdasarkan tabel 8 di atas bahwa dalam pengujian regresi berganda menunjukkan hasil $\mathrm{F}$ hitung sebesar 8,404 dengan tingkat signifikansi $0,000<0,05$, di mana nilai $\mathrm{F}_{\text {hitung }}$ $8,404>\mathrm{F}_{\text {tabel }}$ yaitu sebesar 2,74 (dfl=4-1=3 dan $\left.\mathrm{df} 2=72-4=46\right)$ Hal ini berarti vaiabel lingkungan, psikologi, dan promosi secara bersama-sama berpengaruh terhadap keputusan etnis Tionghoa.

\begin{tabular}{|c|c|c|c|c|c|}
\hline \multirow[b]{3}{*}{ Model } & \multicolumn{3}{|c|}{$\begin{array}{c}\text { Tabel } 9 \\
\text { Hasil Uji t - Uji Parsial } \\
\text { Coefficients }^{\mathrm{a}}\end{array}$} & \multirow[b]{3}{*}{$\mathrm{t}$} & \multirow[b]{3}{*}{ Sig. } \\
\hline & \multicolumn{2}{|c|}{$\begin{array}{l}\text { Unstandardized } \\
\text { Coefficients }\end{array}$} & \multirow{2}{*}{$\begin{array}{c}\text { Standardize } \\
\mathrm{d} \\
\text { Coefficients } \\
\text { Beta } \\
\end{array}$} & & \\
\hline & $\mathrm{B}$ & Std. Error & & & \\
\hline (Constant) & -2.423 & 6.599 & & -.367 & .715 \\
\hline Lingkungan (X1) & 628 & .286 & .229 & 2.193 & .032 \\
\hline Psikologi (X2) & -.028 & .132 & -.022 & -.212 & .833 \\
\hline Promosi (X3) & .462 & .100 & .487 & 4.640 & .000 \\
\hline
\end{tabular}

Berdasarkan tabel 9 di atas maka dapat dijelaskan bahwa:

a. Pada model regresi tersebut memiliki konstanta $-2,423$, hal ini berarti bahwa jika variabel lingkungan, psikologi, dan promosi diasumsikan sama dengan nol, maka keputusan etnis Tionghoa akan menurun sebesar -2,423.

b. Nilai koefisien regresi variabel lingkungan $\left(\mathrm{X}_{\mathrm{l}}\right)$ sebesar 0,628 pada penelitian ini dapat diartikan bahwa ketika lingkungan $\left(\mathrm{X}_{\mathrm{l}}\right)$ mengalami peningkatan sebesar satu satuan,

Iqtishadia: Jurnal Ekonomi dan Perbankan Syariah 
Jasri, Salma Said, Amiruddin K.

maka keputusan etnis Tionghoa akan mengalami peningkatan sebesar 0,628.

c. Nilai koefisien regresi variabel psikologi $\left(X_{2}\right)$ sebesar $-0,028$ pada penelitian ini dapat diartikan bahwa ketika variabel psikologi $\left(\mathrm{X}_{2}\right)$ mengalami peningkatan sebesar satu satuan, maka keputusan etnis Tionghoa akan mengalami peningkatan sebesar -0,028.

d. Nilai koefisien regresi variabel promosi $\left(\mathrm{X}_{3}\right)$ sebesar 0,462 pada penelitian ini dapat diartikan bahwa ketika variabel promosi $\left(\mathrm{X}_{3}\right)$ mengalami peningkatan satu satuan, maka keputusan etnis Tionghoa akan mengalami peningkatan sebesar 0,462.

Hasil interpretasi atas hipotesis penelitian $\left(\mathrm{H}_{1}, \mathrm{H}_{2}, \mathrm{H}_{3}\right)$ yang diajukan dapat dilihat sebagai berikut:

1) Lingkungan berpengaruh positif dan signifikan terhadap keputusan etnis Tionghoa.

Berdasarkan tabel 4.20 dapat dilihat bahwa variabel lingkungan memiliki nilai $t_{\text {hitung }}$ sebesar $2.193>$ nilai tabel sebesar 1,995 (sig. $\alpha=0,05 \mathrm{dan} \mathrm{df}=\mathrm{n}-\mathrm{k}$, yaitu 72-4=68) dengan unstandardized coefficients beta sebesar 0,628 dan tingkat signifikansi 0,032 yang lebih kecil dari 0,05 , maka $\mathrm{H}_{1}$ diterima. Hal ini berarti lingkungan berpengaruh positif dan signifikan terhadap keputusan etnis Tionghoa. Dengan demikian hipotesis pertama yang menyatakan lingkungan berpengaruh positif dan signifikan terhadap keputusan etnis Tionghoa terbukti atau dapat diterima. Hasil penelitian ini menunjukkan bahwa semakin baik dan strategis lingkungan PT. Bank BTN Syariah, maka keputusan nasabah etnis Tionghoa juga akan semakin bertambah.

2) Psikologi berpengaruh positif dan signifikan terhadap keputusan etnis Tionghoa.

Berdasarkan tabel 4.20 dapat dilihat bahwa variabel psikologi memiliki nilai thitung sebesar $-0,212>$ nilai $t_{\text {tabel }}$ sebesar 1,995 (sig. $\alpha=0,05 \mathrm{dan} \mathrm{df}=\mathrm{n}-\mathrm{k}$, yaitu 72-4=68) dengan unstandardized coefficients beta sebesar $-0,028$ dan tingkat signifikansi 0,833 yang lebih besar dari 0,05 , maka $\mathrm{H}_{2}$ tidak diterima. Hal ini berarti psikologi tidak berpengaruh terhadap keputusan etnis Tionghoa. Dengan demikian hipotesis kedua yang menyatakan psikologi berpengaruh positif dan signifikan terhadap keputusan etnis Tionghoa tidak terbukti. Hasil penelitian menunjukkan bahwa faktor psikologi tidak memengaruhi keputusan etnis Tionghoa dalam memilih PT. Bank BTN Syariah Makassar.

3) Promosi berpengaruh positif dan signifikan terhadap keputusan etnis Tionghoa.

Berdasarkan tabel 4.20 dapat dilihat bahwa variabel promosi memiliki nilai $t_{\text {hitung }}$ sebesar 4,640 > nilai tabel sebesar 1,995 (sig. $\alpha=0,05 \mathrm{dan} \mathrm{df}=\mathrm{n}-\mathrm{k}$, yaitu 72-4=68) dengan unstandardized coefficients beta sebesar 0,487 dan tingkat signifikansi 0,000 yang lebih kecil dari 0,05 , maka $\mathrm{H}_{3}$ diterima. Hal ini berarti promosi berpengaruh positif dan signifikan terhadap keputusan etnis Tionghoa. Dengan demikian hipotesis ketiga yang menyatakan promosi berpengaruh positif dan signifikan terhadap keputusan etnis Tionghoa terbukti atau dapat diterima. Hasil penelitian menunjukkan bahwa semakin baik promosi yang dilakukan oleh Bank BTN Syariah Makassar, maka keputusan etnis Tionghoa untuk memilih bank PT. BTN Syariah Makassar akan semakin baik

\section{Pengaruh Lingkungan terhadap Keputusan Etnis Tionghoa Menggunakan Jasa Bank BTN Syariah Makassar.}

Hipotesisi pertama $\left(\mathrm{H}_{1}\right)$ yang diajukand dalam penelitian ini adalah faktor lingkungan berpengaruh positif terhadap keputusan etnis Tionghoa dalam memilih bank BTN Syariah Makassar. Berdasarkan hasil analisis regresi berganda menunjukkan bahwa faktor lingkungan berpengaruh positif dan signifikan terhadap keputusan etnis Tionghoa dalam memilih bank BTN Syariah Makassar, dengan demikian hipotesis pertama diterima. Hal ini menunjukkan bahwa apabila lingkungan suatu lembaga perbankan semakin baik, maka 
semakin tinggi pula pengaruhnya terhadap pengambilan keputusan masyarakat untuk memilih lembaga perbankan tersebut.

Hasil penelitian ini menggambarkan bahwa Bank BTN Syariah Makassar telah merancang dan juga melakukan penerapan lingkungan yang baik. Hal tersebut didasarkan pada asumsi bahwa proses keputusan nasabah terhadap pemilihan suatu lembaga dipengaruhi oleh lingkungan yang mengitarinya. Ketika seorang melakukan pemilihan suatu lembaga didasari oleh banyak pertimbangan, termasuk faktor lingkungan ${ }^{16}$ seperti budaya, kelas sosial, atau keluarga. ${ }^{17}$ Bank BTN Syariah Makassar yang tidak panatik terhadap suatu etnis atau golongan tertentu menjadikan bank tersebut mudah dapat menyesuaikan lingkungan dengan semua etnis dan semua golongan.

Hasil penelitian ini sesuai dengan penelitian yang dilakukan oleh Jalilah dan Muhammad Yasir, ${ }^{18}$ bahwa faktor-faktor lingkungan memiliki pengaruh positif dan signifikan terhadap keputusan nasabah etnis Tionghoa dalam memutuskan pilihannya memilih bank syariah. Hal ini juga didukung oleh teori preference yang lebih berfokus pada pengambilan keputusan konsumen yang melibatkan interaksi antara perilaku dan kejadian di sekitar. Budaya yang diterpakan pada Bank BTN Syariah Makassar yang mampu menyesuaikan semua etnis dan golongan merupakan suatu interaksi sosial yang sangat mempengaruhi daya tarik suatu konsumen dalam menentukan pilihannya terhadap suatu lembaga yang dalam hal ini adalah Bank BTN Syariah Makassar.

\section{Pengaruh Pskologi terhadap Keputusan Etnis Tionghoa Menggunakan Jasa Bank BTN Syariah Makassar.}

Hipotesisi pertama $\left(\mathrm{H}_{2}\right)$ yang diajukand dalam penelitian ini adalah faktor psikologi tidak berpengaruh terhadap keputusan etnis Tionghoa dalam memilih bank BTN Syariah Makassar. Berdasarkan hasil analisis regresi berganda menunjukkan bahwa faktor psikologi tidak berpengaruh terhadap keputusan etnis Tionghoa dalam memilih bank BTN Syariah Makassar, dengan demikian hipotesis kedua ditolak. Hal ini menunjukkan bahwa psikologi seorang konsumen tidak memengaruhi keputusannya dalam menentukan pilihannya terhadap suatu lembaga.

Hasil penelitian ini menggambarkan bahwa faktor psikologi tidak memberikan pengaruh terhadap keputusan nasabah etnis Tionghoa untuk menggunakan jasa bank syariah. Artinya etnis Tionghoa menggunakan jasa bank syariah tidak didasari atas faktor psikologi. Karena mereka memilih bank syariah bukan karena adanya kebutuhan secara khusus atas perbankan syariah ataupun untuk memperoleh status sosial dalam masyarakat tetapi karena adanya dorongan dari lingkungan etnis Tionghoa berada, teman serta keluarga. ${ }^{19} \mathrm{Hal}$ ini sesuai dengan teori preference konsumen menurut Andreasen bahwa perubahan sikap konsumen dapat dipengaruhi oleh berbagai informasi yang diperoleh dari sekelilingnya, baik secara sengaja ataupun tidak sengaja. ${ }^{20}$ Dalam model ini dijelaskan secara

\footnotetext{
16Sutisna, Perilaku Konsumen \& Komunikasi Pemasaran. Bandung: Remaja Rosdakarya, 2003, 6-7. ${ }^{17}$ Basu Swastha, Manajemen Pemasaran Modern, Ed. II; Yogyakarta: Liberty-Yogyakarta, 4.3-4.5.

${ }_{18}$ Muhammad Taufik and Muhammad Yasir, "Mengkritisi Konsep Islamisasi Ilmu Ismail Raji al-Faruqi: Telaah Pemikiran Ziauddin Sardar," Jurnal Ushuluddin Vol. 25 No. 2 (Juli-Desember 2017), 109-123. ${ }^{19}$ Siti Umi Hanik dan Jati Handayani, "Keputusan Nasabah dalam Memilih Perbankan Syariah (Studi Kasus pada Nasabah Bank Syariah Mandiri)”, Jurnal JABPI, Vol. 22 No 2 (JULI 2014), 200.

${ }^{20}$ Alan R. Andreasen, Tanya Jawab: Perilaku Konsumen dan Pemasaran Strategi. Jakarta: Penerbit Harvarindo, 2005, 72.
} 
kronologis tentang seluruh proses perilaku seseorang yang diakibatkan oleh sentuhan informasi yang diperolehnya.

Hasil penelitian ini sejalan dengan penelitian yang dilakukan oleh Hanik dan Handayani, ${ }^{21}$ bahwa berdasarkan hasil yang diperoleh dari penelitian di lapangan, faktor psikologi ternyata tidak memiliki pengaruh terhadap keputusan nasabah memilih perbankan syariah. Hal yang sama dikemukan oleh Ida Nurlaei,,22 bahwa faktor psikologi secara parsial tidak berpengaruh terhadap keputusan nasabah memilih bank syariah. Hasil penelitian ini menunjukkan bahwa motivasi, persepsi, ataupun pembelajaran terhadap suatu kejadian tidak selalu menjadi faktor yang mempengaruhi seseorang dalam menjatuhkan pilihannya menggunakan jasa perbankan syariah.

\section{Pengaruh Promosi terhadap Keputusan Etnis Tionghoa Menggunakan Jasa Bank BTN Syariah Makassar.}

Hipotesisi ketiga (H3) yang diajukan dalam penelitian ini adalah faktor promosi berpengaruh positif terhadap keputusan nasabah dalam memilih bank syariah di Kota Makassar. Berdasarkan hasil analisis regresi berganda menunjukkan bahwa faktor promosi berpengaruh positif dan signifikan terhadap keputusan nasabah dalam memilih bank syariah di Kota Makassar, dengan demikian hipotesis kedua diterima. Hal ini menunjukkan bahwa promosi pada perbankan syariah mempengaruhi keputusan nasabah dalam menentukan pilihannya.

Hasil penelitian ini menggambarkan bahwa semakin baik promosi yang dilakukan oleh perbankan syariah di Kota Makassar maka akan berdampak positif terhadap peningkatan jumlah nasabah pada perbankan syariah. Hasil penelitian ini sejalan dengan penelitan yang dilakukan oleh Evi Yupitri dan Raina Linda Sari, ${ }^{23}$ Maladi Noor, ${ }^{24}$ dan Atika Yuniarti, ${ }^{25}$ bahwa faktor promosi memiliki pengaruh yang positif dan signifikan terhadap keputusan nasabah menggunakan jasa bank syariah. Ketiga hasil penelitian tersebut semakin diperkuat dengan penelitian Kurniati, ${ }^{26}$ bahwa korelasi antara promosi dengan keputusan menjadi nasabah sangat kuat, yaitu semakin efektif promosi yang dilakukan maka semakin meningkat pula keputusan untuk menjadi nasabah pada bank syariah. Namun hasil dari penelitian ini

\footnotetext{
${ }^{21}$ Siti Umi Hanik dan Jati Handayani, "Keputusan Nasabah dalam Memilih Perbankan Syariah (Studi Kasus pada Nasabah Bank Syariah Mandiri)", 200.

${ }^{22}$ Ida Nurlaeli, "Pengaruh Faktor Budaya, Psikologi, Pelayanan, Promosi dan Pengetahuan tentang Produk terhadap Keputusan Nasabah Memilih Bprs di Banyumas", Islamadina: Jurnal Pemikiran Islam, Vol. XVIII No. 2 (Juni 2017), 102.

${ }^{23}$ Evi Yupitri dan Raina Linda Sari, "Analisis Faktor-Faktor yang Mempengaruhi Non Muslim Menjadi Nasabah Bank Syariah Mandiri di Medan" Jurnal Ekonomi dan Keuangan, Vol. 1 No. 1 (Desember 2012), 58.

${ }^{24}$ Maladi Noor, "Pengaruh Faktor Eksternal terhadap Keputusan Nasabah Non Muslim Menggunakan Jasa Pembiayaan Perbankan Syari'ah di Kota Pontianak", Khatulistiwa: Journal Of Islamic Studies, Vol. 07 No. 02 (September 2017), 124.

${ }^{25}$ Atika Yuniarti, "Pengaruh Promosi, Pengetahuan Nasabah dan Motivasi terhadap Keputusan Pengambilan Cicilan Pada Pt Al-Ijarah Indonesia Finance Cabang Lampung", Skripsi (Fakultas Ekonomi Dan Bisnis Islam Universitas Islam Negeri Raden Intan Lampung, 2018), 121.

${ }^{26}$ Kurniati, "Pengaruh Promosi terhadap Keputusan Menjadi Nasabah Produk Tabungan di BRI Syariah Cabang Mataram", Skripsi (Fakultas Syari'ah dan Ekonomi Islam, Universitas Islam Negeri Mataram, 2017), 66.
}

12

$$
\begin{gathered}
\text { Iqtishadia: Jurnal Ekonomi dan Perbankan Syariah } \\
\text { Vol.7 No.1 Juni } 2020
\end{gathered}
$$


berbeda dengan penelitian yang dilakukan oleh Vita Aprilia Safitri,27 bahwa promosi tidak berpengaruh terhadap keputusan nasabah, sedangkan dalam penelitian Muhammad Fajar Fahrudin dan Emma Yulianti, ${ }^{28}$ mengungkapkan bahwa promosi secara parsial berpengaruh positif terhadap keputusan nasabah tetapi tidak signifikan. Hal ini menunjukkan bahwa promosi tidak selalu menjadi hal yang utama dalam proses pengambilan keputusan untuk menabung.

Promosi merupakan upaya pemasaran yang bersifat media dan non media untuk merangsang coba-coba dari konsumen, meningkatkan permintaan dari konsumen atau untuk memperbaiki kualitas produk. ${ }^{29}$ Akan tetapi, masyarakat yang telah menjadi nasabah perbankan syariah tidak selalu membutuhkan promosi untuk mendapat ransangan menggunakan jasa perbankan, karena masyarakat yang merupakan nasabah telah mengenal dan mengetahui keungulan ataupun kekurangan dari produk yang ditawarkan. ${ }^{30}$ Walaupun demikian, bagi masyarakat yang belum menjadi nasabah perbankan syariah, akan membutuhkan informasi tepat dan akurat untuk mengevaluasi sejumlah pilihan untuk menentukan pilihannya. Sehingga promosi yang tepat dan akurat yang dilakukan oleh perbankan syariah akan mempengaruhi peningkatan jumlah nasabah. Teori preference dalam hal ini dapat dilihat dari sikap masyarakat terhadap keputusannya dalam memilih perbankan syariah yang terbentuk melalui variabel promosi. Melalui kegiatan promosi, diharapkan produk dapat diketahui, dikenal dan disukai oleh konsumen atau calon konsumen. Menurut Kotler dan Keller, bahwa promosi merupakan sarana dimana perusahaan berusaha untuk menginformasikan, membujuk dan mengingatkan konsumen baik secara langsung atau tidak langsung tentang suatu produk dan merek yang mereka jual

Berdasarkan pada pemaparan di atas, maka keterkaitan antara promosi dengan teori preferensi bisa dijelaskan sebagai berikut Melalui promosi maka konsumen bisa mengenal bank syariah. Ketika konsumen mengenal bank syariah maka terdapat kemungkinan bahwa bank syariah tersebut dipertimbangkan untuk dikunjungi dan akhirnya kegiatan promosi bisa mempengaruhi keputusan konsumen untuk memilih bank syariah. 2) Melalui promosi maka konsumen bisa memahami diferensiasi setiap bank. Melalui kegiatan promosi, perbankan syariah bisa memberikan alasan yang tepat kenapa harus memilih perbankan syariah. Ketika perbedaan antara bank syariah dengan bank yang lain telah diketahui oleh konsumen atau calon konsumen akan memberikan potensi untuk mempengaruhi keputusannya dalam memilih bank syariah. 3) Melalui promosi maka mengarahkan konsumen untuk tetap menggunajan jasa bank syariah bersangkutan. Untuk itu, kegiatan promosi bisa menjadi preferensi bagi konsumen untuk tetap menggunakan jasa bank syariah di waktu yang akan datang.

\footnotetext{
${ }^{27}$ Vita Aprilia Safitri, "Pengaruh Kualitas Pelayanan, Promosi dan Kepercayaan terhadap Keputusan Nasabah Melakukan Pembiayaan Kredit Usaha Rakyat (Kur) Dengan Brand Image Sebagai Variabel Intervening pada Bank BRI Syariah KCP. Demak", Skripsi. (Fakultas Ekonomi dan Bisnis Islam Institut Agama Islam Negeri Salatiga, 2018), 67.

28Muhammad Fajar Fahrudin dan Emma Yulianti, "Pengaruh Promosi, Lokasi, dan Kualitas Layanan terhadap Keputusan Pembelian Nasabah Bank Mandiri Surabaya", Journal of Business and Banking Volume 5 Number 1 (Mei-Oktober 2015), 149-162.

${ }^{29}$ Sutisna, Perilaku Konsumen dan Komunikasi Pemasaran, Cetakan Ketiga. Bandung: PT. Remaja Rosdakarya, 2003.

${ }^{30}$ Muhammad Fajar Fahrudin dan Emma Yulianti, "Pengaruh Promosi, Lokasi, dan Kualitas Layanan terhadap Keputusan Pembelian Nasabah Bank Mandiri Surabaya", Journal of Business and Banking Volume 5 Number 1 (Mei-Oktober 2015), 149-162.
}

Iqtishadia: Jurnal Ekonomi dan Perbankan Syariah 
Jasri, Salma Said, Amiruddin K.

\section{PENUTUP}

Berdasarkan hasil penelitian dan pembahasan di atas maka kesimpulan dalam penelitian ini dapat diuraikan sebagai berikut:

Hasil analisis data menunjukkan nilai koefisien regresi variabel lingkungan $\left(\mathrm{X}_{\mathrm{l}}\right)$ sebesar 0,628 dan variabel lingkungan memiliki nilai thitung sebesar $2.193>$ nilai tabel sebesar 1,995 dengan unstandardized coefficients beta sebesar 0,628 dan tingkat signifikansi 0,032 yang lebih kecil dari 0,05. Hal ini berarti lingkungan berpengaruh positif dan signifikan terhadap keputusan etnis Tionghoa.

Hasil analisis data menunjukkan nilai koefisien regresi variabel psikologi (X2) memiliki nilai thitung sebesar $-0,212>$ nilai $t_{\text {tabel }}$ sebesar 1,995dengan unstandardized coefficients beta sebesar -0,028 dan tingkat signifikansi 0,833 yang lebih besar dari 0,05 , maka $\mathrm{H}_{2}$ tidak diterima. Hal ini berarti psikologi tidak berpengaruh terhadap keputusan etnis Tionghoa.

Hasil analisis data menunjukkan nilai koefisien regresi variabel promosi memiliki nilai thitung sebesar 4,640 > nilai tabel sebesar 1,995 dengan unstandardized coefficients beta sebesar 0,487 dan tingkat signifikansi 0,000 yang lebih kecil dari 0,05, maka $\mathrm{H}_{3}$ diterima. Hal ini berarti promosi berpengaruh positif dan signifikan terhadap keputusan etnis Tionghoa.

\section{DAFTAR PUSTAKA}

Adhipratama, Agung Anugerah. "Analisis Faktor-Faktor yang Memengaruhi Keputusan Nasabah Non-Muslim untuk Menggunakan Bank Syariah". Tesis. Yogyakarta: Pascasarjana Fakultas Ekonomi, Universitas Islam Indonesia, 2018.

Akbar, Harviz dan Haroni Doli H. Ritonga. "Persepsi Etnis China terhadap Perbankan Syariah di Kota Medan". Jurnal Ekonomi dan Keuangan 1, No. 2 (Januari 2013).

Alma, Buchari. Manajemen Pemasaran dan Pemasaran Jasa. Bandung: Alfabeta, 2007.

Al-Qurtubi, Al-Jami' li Ahkam Al-Quran, Vol. 9.

Andreasen, Alan R. Tanya Jawab: Perilaku Konsumen dan Pemasaran Strategi. Jakarta: Penerbit Harvarindo, 2005.

Arikunto, S., Prosedur Penelitian Suatu Pendekatan Praktik. Jakarta: Rineka Cipta, 2010.

Badan Pusat Statistik Sulawesi Selatan. diakses dari https://sulsel.bps.go.id/quickMap.html pada 07 November 2019

Dagun, M. Save. Kaus Besar Ilmu Pengetahuan. Jakarta: Lembaga Pengajian Kebudayaan Nusantara (LPKN), 2006.

Dharmesta, Basu Swastha. Manajemen Pemasaran. Yogyakarta: BPFE, 2014.

Fahrudin, Muhammad Fajar dan Emma Yulianti. "Pengaruh Promosi, Lokasi, dan Kualitas Layanan terhadap Keputusan Pembelian Nasabah Bank Mandiri Surabaya”. Journal of Business and Banking. Volume 5 Number 1 (Mei-Oktober 2015).

Hanik, Siti Umi dan Jati Handayani. "Keputusan Nasabah dalam Memilih Perbankan Syariah (Studi Kasus pada Nasabah Bank Syariah Mandiri)". Jurnal JABPI, Vol. 22 No 2 (JULI 2014).

Howard, John A. and Jagdish N. Sheth. Consumer Behavior and Marketing Strategy. Irwin Mc Graw Hill., 1998.

Jasri, Jasri. "Pendapatan Margin Bayal-Murabahah Terhadap Profitabilitas Pada Bank Syariah." Jurnal Hukum Ekonomi Syariah 1.1 (2017): 64-73. 
Karim, Adiwarman A. Bank Islam: Anatisis Fiqh dan Keuangan. Jakarta: PT. Raja Grafindo Persada, 2010Kotler, Philip. The Consumer Behavior in Marketing Management. Published by Simon \& Schuster Pte.Ltd, 1999.

Kasmir. Pemasaran Bank. Jakarta: Kencana, 2010.

Kotler, Philip dan Armstrong, Prinsip - Prinsip Manajemen Pemasaran. Ed. XII; Jilid 2; Jakarta: Erlangga, 2009.

Kurniati. "Pengaruh Promosi terhadap Keputusan Menjadi Nasabah Produk Tabungan di BRI Syariah Cabang Mataram". Skripsi (Fakultas Syari'ah dan Ekonomi Islam, Universitas Islam Negeri Mataram, 2017).

Misbach, Irwan. Bank Syariah: Kualilas Iayanan, Kepuasan, dan Kepercayaan. Cet. I; Makassar; Alauddin University Press, 2013.

Nujaim, Ibn. Al-Ashbah wa Al-Nadhair. dan Al-Fawakih Al-Dawani, Vol. 2.

Nurlaeli, Ida. "Pengaruh Faktor Budaya, Psikologi, Pelayanan, Promosi dan Pengetahuan tentang Produk terhadap Keputusan Nasabah Memilih Bprs di Banyumas". Islamadina: Jurnal Pemikiran Islam, Vol. XVIII No. 2 (Juni 2017).

Noor, Maladi. "Pengaruh Faktor Eksternal terhadap Keputusan Nasabah Non Muslim Menggunakan Jasa Pembiayaan Perbankan Syari'ah di Kota Pontianak". Khatulistiwa: Journal Of Islamic Studies, Vol. 07 No. 02 (September 2017).

Pratama, Agung Anugerah Adhi. "Analisis Faktor-Faktor yang Mempengaruhi Keputusan Nasaban Non Muslim untuk Menggunakan Bank Syariah". Tesis. (Yogyakarta: Pascasarjana Fakultas Ekonomi, Universitas Islam Indonesia, 2018).

Purwanto. Evaluasi Hasil Belajar. Yogyakarta: Pustaka Belajar, 2011.

Rostanti. "Non Muslim Makin Minati Produk Bank Syariah". diakses dari http://www.republika.co.id./berita/ekonomi/syariahekonomi/13/02/21/mikep8nonmuslim-makin-minati-produk-bank-syariah. pada 11 April 2019.

Rupaida, Afifah, dkk. "Pengaruh Komunikasi Pemasaran terhadap Keputusan Pembelian Produk Makanan dalam Kemasan Berlabel Halal pada Masyarakat Muslim Bumi Asri (Studi Kasus Pada Sb Mart Bumi Asri)". Prosiding Keuangan \& Perbankan Syariah; Vol 1, No 2, (Agustus 2015).

Rufaida, Erty Rospyana, and Alamsyah Alamsyah. "Metode Pengakuan Pendapatan Bagi Hasil." Jurnal Hukum Ekonomi Syariah 3.1 (2019): 27-39.

Safitri, Vita Aprilia. "Pengaruh Kualitas Pelayanan, Promosi dan Kepercayaan terhadap Keputusan Nasabah Melakukan Pembiayaan Kredit Usaha Rakyat (Kur) Dengan Brand Image Sebagai Variabel Intervening pada Bank BRI Syariah KCP. Demak". Skripsi. (Fakultas Ekonomi dan Bisnis Islam Institut Agama Islam Negeri Salatiga, 2018).

Sutisna. Perilaku Konsumen \& Komunikasi Pemasaran, Bandung: Remaja Rosdakarya, 2003.

Swastha, Basu. Manajemen Pemasaran Modern. Ed. II; Yogyakarta: Liberty-Yogyakarta.

Taufik, Muhammad and Muhammad Yasir. "Mengkritisi Konsep Islamisasi Ilmu Ismail Raji alFaruqi: Telaah Pemikiran Ziauddin Sardar." Jurnal Ushuluddin Vol. 25 No. 2 (JuliDesember 2017).

Umam, Khaerul. Manajemen Perbankan Syariah. Cet. I; Bandung: Pustaka Setia, 2013.

Undang-Undang No. 21 Tahun 2008. Tentang Perbankan Syariah. Pasal 1 Ayat 7.

Yuniarti, Atika. "Pengaruh Promosi, Pengetahuan Nasabah dan Motivasi terhadap Keputusan Pengambilan Cicilan Pada Pt Al-Ijarah Indonesia Finance Cabang Lampung". Skripsi (Fakultas Ekonomi Dan Bisnis Islam Universitas Islam Negeri Raden Intan Lampung, 2018). 
Jasri, Salma Said, Amiruddin K.

Yupitri, Evi dan Raina Linda Sari. "Analisis Faktor-Faktor yang Mempengaruhi Non Muslim Menjadi Nasabah Bank Syariah Mandiri di Medan". Jurnal Ekonomi dan Keuangan, Vol. 1 No. 1 (Desember 2012). 